\title{
Marketing Strategies and New Focus for Luxury Companies under COVID-19 Pandemic
}

\author{
Yilin Peng ${ }^{1, *}$ \\ ${ }^{1}$ Temasek Junior College, Singapore 518089 \\ *Corresponding author.Email: peng_yilin@temasekjc.moe.edu.sg
}

\begin{abstract}
This research paper investigates the transformation of marketing strategies for luxury companies due to the impact of economic crisis resulted from COVID-19 pandemic. Taking International Brands as examples, this paper analyses from psychology of consumers to global economic performance in order to best examine the responses of luxury industries under pandemic as well as their new focus on marketing strategies. Luxury goods are greatly restricted by global economic outlook, consumer purchasing power and even consumer's mindset. Hence, this paper aims to contribute to the luxury industry by providing new insights in methods to improve sells for luxury goods. Eventually, this paper concludes that under the challenge of COVID-19 pandemic, only a few luxury companies responded in an efficient and competent manner. The conventional pricing and marketing system could be enhanced to deal with more complicated issues under more complex context.
\end{abstract}

Keywords: Marketing strategy, luxury goods, COVID-19, economic crisis

\section{INTRODUCTION}

Luxury-something expensive that is pleasant for people to have but is not necessary by its definition. In economics, the quantity demanded for luxury goods increase more than proportional to the decrease in its own price. Since its very own nature defines its price elasticity, luxury goods are often consumed or perceived to be consumed by a small population of privileged people [1]. With rapid economic development and income growth, more and more people are able to purchase luxury goods [2]. The expansion in the type of consumers purchasing luxury goods marks the shift of the focus of luxury companies. Hence, the elements affecting the change in focus become decisive in the company's decision-making process. These include social, environmental and cultural factors [3]. However, the COVID-19 pandemic had struck the economy worldwide and caused a financial crisis, thus greatly decreased the purchasing power of the potential consumers. This paper aims to suggest the modifications to the international marketing strategies for luxury industry under COVID-19 pandemic. Meanwhile, this paper seeks to compare between different factors and assess which is the fundamental factor in influencing the marketing strategies.

\section{TRADITIONAL MARKETING STRATEGIES FOR LUXURY BRANDS}

Traditionally, luxury companies operate in a profitdriven goal, aiming to achieve economic of scales [4]. First of all, luxury brands often adapt an unique and simple $\log$ o for consumers to quickly recognize the brand and leave an strong impression. For example, the monogram of LV and the double $\mathrm{C}$ of Chanel has saved them from being outdated in the fashion industry and has now became their biggest selling point. Secondly, luxury industries used to express the idea of 'scarcity' [5]. The use of rare materials and excessive labour in the process of making one piece of product explains the high price. However, globalization has improved the movement and allocation of resources. This high mobility of labour and resources reduces the cost of production and the quantity rises as well. Lastly, economists assumed that consumers are 'rational decision makers' in purchasing goods and services [6]. In real life, it is not necessarily true. Apart from those wealthy consumers, a main target audience of luxury brands is those 'irrational consumers' [7] who are easily motivated by emotions. Pictures that convey a story or a message is more powerful in stirring emotions among consumers than words. This elucidates why visual 


\begin{tabular}{|c|c|c|c|c|c|}
\hline \multirow[t]{5}{*}{ stimulations } & are & comı & used & adve & tisements (see Figure 1). \\
\hline & & $\begin{array}{l}\text { Brand and } \\
\text { Commercial }\end{array}$ & $\begin{array}{l}\text { Explanation of } \\
\text { Advertisement }\end{array}$ & Demographics & Psychological Response Elicited \\
\hline & & $\begin{array}{l}\text { Amazon.com } \\
\text { "Shopping App" }\end{array}$ & $\begin{array}{l}\text { Average looking people } \\
\text { are shown using their } \\
\text { smartphones to look up } \\
\text { the products they are } \\
\text { shopping for in stores on } \\
\text { Amazon.com. }\end{array}$ & $\begin{array}{l}\text { Men and } \\
\text { Women 20-60 }\end{array}$ & $\begin{array}{l}\text { Convenience - The ad suggests that the } \\
\text { Amazon.com app makes it easy to buy } \\
\text { products online that you encounter in } \\
\text { your everyday life. }\end{array}$ \\
\hline & & ESPN "Watch Live" & $\begin{array}{l}\text { A stereotypical looking } \\
\text { cowboy sits atop a horse } \\
\text { deep in the dessert. As } \\
\text { he begins to wrangle } \\
\text { cattle, he watches sports } \\
\text { and live broadcasts from } \\
\text { ESPN. }\end{array}$ & Men 25-50 & $\begin{array}{l}\text { Accessibility - If a rough cowboy in a } \\
\text { remote location can access all of his } \\
\text { favorite sports content, then anyone can } \\
\text { access it from anywhere. The } \\
\text { commercial suggests to ESPN viewers } \\
\text { that they can watch sports anywhere, } \\
\text { even when they are on the go. }\end{array}$ \\
\hline & & $\begin{array}{l}\text { Fixel "Living } \\
\text { Photos" }\end{array}$ & $\begin{array}{l}\text { A couple is shown } \\
\text { photographing their } \\
\text { young daughter on her } \\
\text { birthday. Using the Fixel } \\
\text { app, the father animates } \\
\text { the picture and loads it } \\
\text { instantly to the internet. }\end{array}$ & $\begin{array}{l}\text { Men and } \\
\text { Women 20-40 }\end{array}$ & $\begin{array}{l}\text { Sentimentality - The ad positions the } \\
\text { Fixel app as a bridge between your real } \\
\text { life and the social media sites where you } \\
\text { share memories with friends and family. } \\
\text { It uses a sentimental moment to suggest } \\
\text { that sharing is important. }\end{array}$ \\
\hline
\end{tabular}

Figure 1. Marketing strategies targeting consumer emotions

The COVID-19 pandemic resulted in a chaotic market and stagnant economy. This unfavourable change in consumers' taste and preferences towards luxury goods, due to the worsening of global economy, posted new challenges in the marketing strategies for luxury brands. In order to deal with these emerging challenges, it is urgent for luxury companies to employ creative and methodical strategies in overcoming these difficulties.

\section{NEW CHALLENGES FACED BY LUXURY BRANDS UNDER DIFFICULT CIRCUMSTANCES}

There are several factors that made luxury companies especially vulnerable in marketing their products during pandemic.

\subsection{Economic challenges}

Economically, due to the lockdown and constrictions in most of the countries, economic activities fall dramatically. The purchasing power of most consumers decreases because of the reduction in their income growth or earning. The income elasticity of demand for luxury goods is positive and more than 1 [8]. When the income of consumers decreases, the demand for luxury goods falls by a lot (see Figure 2 )When facing economic hardship like COVID-19, most consumers tend to spend their income on necessities like staple food instead of luxury goods such as branded bags and accessories. For example, Victoria's Secret declared bankrupt due to their inability to cover their rent. Swarovski, a famous jewellery brand also decided to close some of their brick and mortar stores to better improve their selling models. This suggests that the lockdown caused by COVID-19 has indeed post a great challenge on luxury companies especially on their sales. Problems like high rent, low or even no economic activities and lack of necessity reinforce the importance of marketing strategies for luxury industry [9].

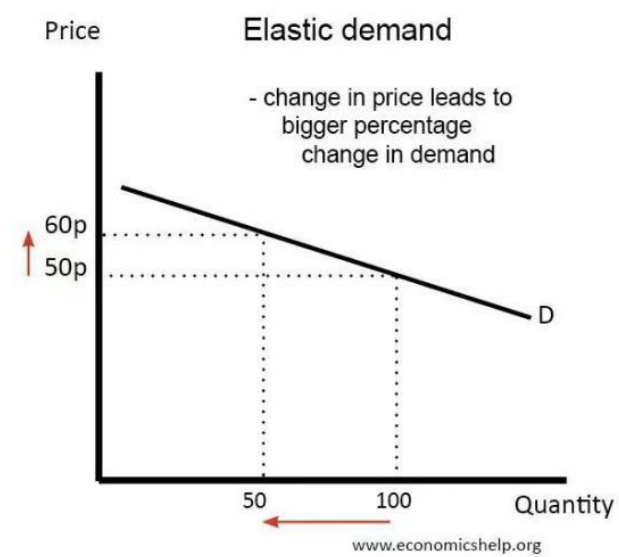

Figure 2. The responsiveness of demand change when price of the luxury goods change

\subsection{Political challenges}

Politically, during COVID-19 and even before the breakout of the pandemic, national leaders and policy makers would suggest citizens save up their income in case there is an emergency. In some countries like Singapore, there is a compulsory saving scheme to encourage citizens to spend their income with cautions. In addition, it would not be politically favoured if luxury brands spend too much on advertising their goods and services during pandemic. Moreover, luxury goods are also extremely vulnerable against any change 
in currency exchange rate. When the Swiss National Bank announced the abandonment of its minimum exchange rate policy, luxury companies were in crisis because such policy would reduce the amount of luxury exports from Switzerland by raising its price in other currency.[10] In the aftermath of COVID-19 pandemic, government certainly adopt some measures to pump up the economy. One of its measures is to encourage economic transactions within the country by promoting local brands and stores. Even till now, most well recognized luxury brands come from Europe and Western countries. Luxury goods may not be the priority of government's plan in reenergizing economy.

\subsection{Ethical challenges}

On the ethical level, consumers are facing critical challenges like unemployment, inability to pay back rent and even starvation due to the lack of resources and economic activities. The core spirit of luxury goods is something extravagant, scarce and lavish. These are contrary to what people needed during pandemic. Hence, some critics might condemn any marketing method or intention from luxury industry to encourage sales during pandemic. John Galliano, the fashion designer of Christian Dior in 1997. He believes in using expansive and lavish materials to present the beauty of lady's curve. Although his fashion style was approved and imitated by many people, his way of designing was still heavily criticised by the public, accusing him of wasting resources. In most Asian countries, the cultural belief of conservation also go against the value of luxury goods. It is therefore extremely challenging for luxury brands to persuade consumers to support them during the pandemic. This involves luxury brand attachment and brand loyalty, which requires a sustained period of time and effort to build [11]

\section{PROPOSALS FOR SOLUTIONS AND NEW FOCUS OF LUXURY INDUSTRY}

It is urgent and necessary to improve on the existing marketing strategies and find a new focus for luxury industry.

First of all, most luxury brands emphasize on the brand's value and meaning instead of the price of the products. For example, Karl Lagerfeld has the reputation of 'the Ceaser of the fashion industry' [12]. Thus, when he was working as creative director in Chanel, the price and reputation of Chanel was at its peak. Nowadays people would still purchase Chanel as a mean to show respect and recognition for him. As the real world situation becomes more and more complex, people are looking beyond the values that this brand or designer has [13]. How luxury company responds to the pandemic also represent their values and morality as a brand, helping the brands attract wider and more targeted consumers. From Armani to Gucci, luxury brands has demonstrated their goodwill in fighting COVID-19 virus. Armani group, including Emporio and Giorgio, announced that 'All of its manufacturing plants will switch from luxury goods creation to making single-use medical overalls' [14]. In the mean time, Gucci donated two millions euro 'in support of two crowd funding campaigns' [15]. All these responses demonstrated their care and support for global issues, which would help them advertise as well as gain a good reputation in supporting the society.

Moreover, luxury brands rely on its leerily production process. Industrialization has improved the efficiency of luxury goods production. Environmental problems like global warming posted a negative impact on the reputation of luxury goods because of its lavish characteristics. Dior has once focused on the extravagant use of luxurious materials to show the beauty of women body shape. By switching to a more sustainable and environmentally friendly materials would be a new selling point for luxury companies. Furthermore, luxury industries could focus on the intangible aspect such as morality to modify their advertisements. Most people follow the trend when they are setting their fashion style. The role of the people in fashion industry is to set the trend. Therefore, the message sent to the consumers is critical as they would also follow the same value. Fighting for human rights such as gender equality is one example in which luxury brands could focus on a new advertising aspect. In contrast, those brands that demonstrated a poor morality like Dolce \& Gabanna, which was racist against the Chinese people received harsh criticism as well as boycotting their products [16]. Therefore, it is crucial for luxury industry to focus on more than just quality and quantity. Instead, it needs to take current affairs to update their advertising strategies on time into account.

Social media has fully integrated into our lives now - especially for Generation Z, the influential consumer group of luxury goods. The impact of social media like Instagram and Snapchat is significant for luxury brands to attract potential consumers and build up their reputation. People now concern about keeping up with their social network life, to get the ideal personal image on social media. Luxury brands become a tool for consumer to help them shape their personal image online. In the future, consumer is expecting more than just 'quality' and 'craftmanship' but also an idea or a story the brand is telling. Hence, creating a value and belief that consumers want to associate with is ultimate critical for a brand. Providing and delivering something that intrigue and motivate people to share on social media is decisive in the marketing strategies of luxury brands. 


\section{CONCLUSION}

To sum up, all three factors including social, cultural and environmental factors are influential in marketing luxury goods. Social factors such as change in the consumer lifestyle and mindset is the underlying element for this change in marketing strategy while environmental problems reinforces this need to change and accelerated the changing. This paper concludes that luxury goods have a clear disadvantage as compared to normal goods due to their difference in degree of necessity. This disadvantage has been amplified during the pandemic because of the economic recession. Hence, the marketing strategies of luxury goods need to be urgently improved for new challenges, namingly financial and economical crisis, change in political tactics. Since this thesis mainly focuses on luxury goods during pandemic, it may not be the best or most suitable reference of marketing strategies of luxury goods in general. Since the aspect and ankle of observation of this paper is specific, the author may further study and discuss wider aspect of marketing strategies for luxury goods. Companies can adopt a mix of demographic and psychographic segmentation to identify potential consumers.

\section{ACKNOWLEDGMENT}

First and foremost, I would like to show my deepest gratitude to my teachers and tutors in my college, who have provided me with valuable guidance in every stage of the writing of this thesis. Their professional knowledge has helped this thesis to be academically more accurate and useful. Further, I would like to thank my friends for their encouragement and support. Without all their enlightening instruction and impressive kindness, I could not have completed my thesis.

\section{REFERENCES}

[1] Wiedmann, K. P., Hennings, N. and Siebels, A. (2012) What is the value of luxury? Psychology \& Marketing.

[2] Frank, R. (2011) Who is buying all that luxury? Not the rich. The Wall Street Journal, 12 January.

[3] Daniel Langer. 2020. Luxury 2030: Curated Lifestyles Drastically Change How Luxury Brands Need to Act. https://jingdaily.com/luxury-2030curated-lifestyles-drastically-change-how-luxurybrands-need-to-act/

[4] The Luxury Strategy: Break the Rules of Marketing to build Luxury Brands. Jean-Noel Kapferer, Vincent Bastien

[5] Oliver Francis Koch, Alexander Benlian. 2015. Promotional Tactics for Online Viral Marketing
Campaigns: How Scarcity and Personalization Affect Seed Stage Referrals

[6] Steven M Shugan. 2006. Are Consumer Rational? Experimental Evidence?

[7] Fan Lei. 2019. A Research on Behavior Irrational Consumption of Chinese Consumers - About the Iphone

[8] Tejvan Pettinger. 2019. Price Elasticity of Demand (PED) https://www.economicshelp.org/microessays

[9] Jean-Noel Kapferer and Laurent, G. (2012) Luxury price thresholds, an international comparison. HEC Paris Research Reports. Jouy-en Josas France.

[10] Lyu Chang, Wang Wen. China Daily. Policy shifts to hit luxury goods.https://www.chinadaily.com.cn/business/201 5-01/17/content_19340514.htm

[11] Shimul A S , Phau I . Consumer advocacy for luxury brands $[\mathrm{J}]$. Australasian Marketing Journal (AMJ), 2018, 26( 3):264-271.

[12] Vogue. 2017. 5 Times Karl Lagerfeld Said Vive la France and Showed Chanel Resort at Home.https://www.vogue.com/article/fashionrunway-karl-lagerfeld-chanel-cruise-2018

[13] The New Strategic Brand Management. Jean-Noel Kapferer

[14] Armani. 2020. COVID-19 Emergency. https://www.armani.com/experience/cn/corporate/s ocial-responsibility/covid-19-emergency/

[15] Gucci. 2020. Gucci Community For COVID-19. https://www.gucci.com/us/en/st/stories/inspirations -and-codes/article/gucci-donation-covid-19

[16] Understanding luxury consumption in China: Consumer perceptions best-known brands. Lingjing Zhan, Yanqun He. October 2012. 